\title{
PENGUATAN PENDIDIKAN KARAKTER PROFESSIONAL-RELIGIUS PADA JAMAAH MAJELIS TAKLIM SHIROTOL MUSTAQIM SEMARANG
}

\section{STRENGTHENING CHARACTER PROFESIONAL-RELIGIOUS EDUCATION OF JAMAAH MAJELIS TAKLIM SHIROTOL MUSTAQIM SEMARANG}

\author{
Saridudin, Ta'rif \\ Puslitbang Pendidikan Agama dan Keagamaan, Badan Litbang dan Diklat Kementerian Agama RI \\ email: dudinsaridudin@gmail.com
}

Naskah Diterima: 24 Januari 2021; Direvisi: 15 November 2021; Disetujui: 28 November 2021

\begin{abstract}
This study aims to examine the implementation of strengthening character education in Jamaah Majelis Taklim Shirotol Mustaqim of Semarang City to respond to the implementation of PMA No. 29 of 2019 concerning Majelis Taklim. This research is qualitative research with a case study approach. Data collection is done by observation, interviews, and document searches. This study resulted in the finding that the socialization of PMA No.29 had not been carried out optimally in the city of Semarang. Majelis Taklim Shirotol Mustaqim has not yet received more in-depth information on how the PMA should be implemented, but substantively accepts what is contained in it. PMA No. 29 is urgently needed by Majelis Taklim to strengthen character education and to fortify society from radicalism and to realize a commitment to religious moderation. The effort made by Majelis Taklim is to develop character through professional-religious concepts. Professionalism is realized by congregations who have the expertise (skills) and live independently in social life. While religious character is reflected in the morality of al-karimah and understands Islam well. This study suggests that: (1) Strengthening the professional-religious character needs to be implemented more clearly in Majelis Taklim, (2) Ministry of Religion is more intense in conducting better socialization regarding the implementation of PMA No. 29 of 2019, (3) Ministry of Religion makes a more detailed technical guidance regarding the implementation of PMA No. 29.
\end{abstract}

Keywords: Character education; Majelis Taklim; PMA No. 29; Professional-religious

\begin{abstract}
Abstrak
Penelitian ini bertujuan untuk mengkaji implementasi penguatan pendidikan karakter professionalreligius pada jamaah Majelis Taklim Shirotol Mustaqim Kota Semarang dalam upaya merespons implementasi PMA No. 29 tahun 2019 tentang Majelis Taklim. Penelitian ini merupakan penelitian kualitatif dengan pendekatan studi kasus. Pengumpulan data dilakukan dengan observasi, wawancara dan penelusuran dokumen. Penelitian ini menghasilkan temuan bahwa upaya yang dilakukan Majelis Taklim Shirotol Mustaqim ialah dengan pengembangan karakter melalui konsep profesional-religius. Profesional diwujudkan dengan jamaah yang memiliki keahlian serta hidup mandiri dalam kehidupan bermasyarakat. Sedangkan religius tercermin dalam akhlak al-karimah serta memahami Agama Islam dengan baik. Majelis Taklim Shirotol Mustaqim belum mendapatkan informasi yang lebih dalam tentang bagaimana PMA itu harus diimplementasikan, namun secara substantif menerima apa yang terkandung di dalamnya. PMA No. 29 sangat dibutuhkan oleh Majelis Taklim dalam rangka penguatan karakter jamaah untuk membentengi masyarakat dari paham radikalisme dan dalam upaya mewujudkan komitmen pada moderasi beragama. Penelitian ini menyarankan agar: (1) Penguatan karakter professional-religius perlu diimplementasikan secara lebih nyata di Majelis Taklim, (2) Kementerian Agama hendaknya lebih intens melakukan sosialisasi dengan lebih baik tentang implementasi PMA No. 29 tahun 2019, (3) Kementerian Agama hendaknya membuat Juknis yang lebih rinci terkait implementasi dari PMA No 29.
\end{abstract}

Kata kunci: Majelis Taklim; Pendidikan karakter; PMA No. 29 tahun 2019; Profesional-religius 


\section{PENDAHULUAN}

Majelis Taklim adalah salah satu lembaga pendidikan Islam non-formal yang sangat popular hingga saat ini. Bahkan masuknya Islam di Nusantara sekitar abad ke 7 Masehi diperkirakan lewat majelis taklim, walaupun waktu itu belum formal disebut majelis taklim, akan tetapi pertemuan dan kelompok yang dilaksanakan di masjid-masjid tergolong sebagai bentuk majelis taklim dengan melihat bentuk-bentuk majelis taklim saat ini (St. Marwiyah, 2020). Majelis Taklim bukan hanya bergerak dalam bidang keagamaan melainkan juga di bidang sosial dan budaya. Dalam bidang keagamaan biasanya meliputi pengajian, membaca AlQuran, dan hal-hal yang berkaitan dengan ibadah. Dalam bidang sosial budaya, Majelis Taklim berusaha untuk meluruskan adat atau budaya yang melenceng dari ajaran Islam yang berkembang di masyarakat (Ibrahim et al., 2020).

Keberadaan Majelis Taklim dengan segala aktivitasnya di Indonesia dapat dipetakan secara umum menjadi dua, yaitu sebagai media dakwah, dan pusat pembelajaran agama. Sebagai media dan organisasi dakwah, majelis taklim dapat dikatakan sebagai fenomena unik, mengapa, selain merupakan produk dan hasil dari kebudayaan dan peradaban yang telah dicapai oleh umat Islam di abad modern ini, lembaga ini juga berakar dari gerakan dakwah yang dilakukan oleh Rasulullah SAW dahulu. Bahkan majelis taklim telah memberikan makna tersendiri dalam dakwah dan pengembangan masyarakat serta menjadi salah satu bentuk dan cara dalam melakukan sosialisasi, internalisasi, eksternalisasi ajaran Islam, khususnya untuk kaum ibu-ibu di semua lapisan masyarakat (Bimas Islam, 2013).

Majelis Taklim sebagai organisasi dakwah masyarakat yang signifikan di masyarakat, memiliki otoritas yang sering kali dikaitkan dengan beberapa kepentingan seperti: 1) Kepentingan pemerintah. Majelis Taklim acapkali dijadikan sebagai ranah sosialisasi program-program dan kebijakan pemerintah baik dalam scope kecil maupun besar, 2) Kepentingan kelompok atau golongan. Sering kali keberadaan majelis taklim dan pengajian yang diselenggarakan dijadikan ajang sosialisasi visi dan misi suatu kelompok tertentu seperti parpol, ormas dan lain sebagainya, 3) kepentingan Individu. Tak jarang Majelis Taklim didirikan dan dibentuk oleh seseorang dengan maksud menggait masa untuk suatu kepentingan, 4) kepentingan Pendidikan. Dengan munculnya berbagai varian pemahaman keagamaan maka tidak jarang Majelis Taklim didirikan dengan maksud untuk menanamkan pemahaman tertentu kepada para jamaahnya (Dahlan, 2018).

Selain beberapa fungsi tersebut, Majelis Taklim juga berfungsi sebagai pusat pembelajaran agama (the centre of Islamic learning), bahkan saat ini banyak juga yang berfungsi sebagai tempat belajar berwirausaha. Majelis Taklim mampu memberikan pengetahuan keagamaan, membentuk akhlak dan moral, internalisasi nilai-nilai luhur keagamaan yang pada akhirnya diharapkan untuk mampu menjadi problem solver bagi problematika yang dihadapi oleh masyarakat (Sarbini, 2010). Majelis taklim sebagai lembaga pendidikan non-formal yang sifatnya tidak terlalu mengikat dengan aturan yang ketak dan tetap merupakan lembaga pendidikan yang efektif dan efisien, cepat menghasilkan dan sangat baik meningkatkan kesadaran umat Islam karena dapat digemari oleh masyarakat luas.

Namun baru-baru ini publik dikejutkan dengan lahirnya PMA No. 29 Tahun 2019 tentang Majelis Taklim. PMA ini mendapat respons dari sebagian masyarakat yang menganggap terlalu membatasi dan mengatur kebebasan berorganisasi yang ada di majelis taklim. Dalam hal ini pemerintah dinilai terlalu masuk ke ranah agama. Seharusnya pemerintah lebih fokus mengurusi permasalahan penting bangsa lainnya yang lebih besar seperti perekonomian dan kesejahteraan masyarakat. Belum lagi dalam PMA tersebut terdapat unsur ketidaktegasan dan ketidakkonsistenan dalam penerapan kebijakan ini. Sehingga tidak heran jika efektivitas PMA No. 29 Tahun 2019 bagi majelis taklim ini sangat dipertanyakan.

Banyak pihak yang menilai bahwa hadirnya produk PMA No. 29 Tahun 2019 ini adalah bagian dari asumsi pemerintah terhadap 
adanya gerakan Islam garis keras atau radikalisme dan ekstrimisme yang sebagian dilakukan oleh umat Islam garis keras yang ada hubungannya dengan majelis taklim, karena lembaga ini merupakan salah satu media dalam penyampaian ajaran-ajaran Islam. Penerbitan PMA ini adalah bentuk kegundahan pemerintah terhadap kasus Radikalisme (deradikalisasi) yang terjadi di Indonesia, yaitu sebuah isu global yang selanjutnya dipolitisasi untuk menjadi isu utama nasional di Indonesia yang sedang mengalami kebangkitan gerakan keislaman. Sikap ini bisa jadi bentuk diskriminasi pemerintah terhadap umat Islam. Seakan-akan setiap tindakan radikalisme selalu disematkan kepada Islam. Selain itu pengesahan PMA tentang majelis taklim ini hanya sebuah Islam fobia atau bentuk ketakutan pemerintah terhadap Islam semata. Sikap pemerintah tersebut pada akhirnya menimbulkan banyak kritik di antaranya terkait dengan urgensi, prosedur, serta regulasi dalam pembuatan kebijakan PMA No. 29 Tahun 2019 ini.

Namun di sisi lain pemerintah melalui Kementerian Agama beralasan bahwa penerbitan PMA ini adalah dalam rangka wujud kehadiran pemerintah dalam manajemen kontrol terhadap majelis taklim sehingga pemerintah dapat mengetahui data real serta kondisi majelis taklim yang ada di Indonesia. Selain itu juga agar pemerintah dapat membantu setiap majelis taklim dari sisi peningkatan kualitas baik pada aspek pengajaran dan kelembagaan serta mengenai pendanaan. Pada aspek lain Kemenag berargumentasi bahwa pengeluaran PMA No. 29 tahun 2019 tentang pengaturan majelis taklim ini untuk membentengi masyarakat dari paham radikalisme serta memperkuat pemahaman dan pengajaran agama Islam yang Rahmatan Lil 'Alamin, yaitu ajaran agama Islam yang menjunjung tinggi toleransi, keinklusifan dan kesantunan di tengah masyarakat multikultural.

Terlepas dari pro dan kontra terhadap PMA tersebut, kajian ini melihat bahwa peran majelis taklim bukan hanya sebagai media dakwah Islam dan sarana pendidikan agama, tapi majelis Taklim dapat berfungsi sebagai media penguatan pendidikan karakter, khususnya karakter yang menekankan pada profesionalisme dan religiositas. Hal inilah yang menjadi fokus peneliti dalam melakukan kajian terhadap Majelis Taklim Shirotol Mustaqim yang merupakan majelis taklim binaan LDII Kota Semarang, dengan harapan penguatan pendidikan karakter ini dapat memperkuat terwujudnya moderasi beragama di Indonesia.

Sebagai komitmen pada penguatan pendidikan karakter ini, Majelis Taklim Shirotol Mustaqim mengembangkan konsep "Profesional-Religius" dalam upaya mendidik jamaahnya. Yang dimaksud profesional ialah mempunyai keahlian (skill) serta hidup mandiri dalam menjalankan kehidupan bermasyarakat. Sedangkan religius ialah memiliki akhlak alkarimah serta memahami Agama Islam dengan baik. Dalam melakukan edukasi kepada jamaah, Majelis Taklim Shirothol Mustaqim, mengembangkan konsep Tri Sukses Pembinaan Penerus yaitu 1) Faham agama (aalim), 2) akhlakul karimah dan 3) mandiri.

Kajian yang secara khusus membahas Majelis Taklim yang berada di bawah naungan LDII memang masih terbatas, kajian yang ada lebih cenderung pada aspek dakwah dan pendidikan agama Islam, belum menekankan bagaimana Majelis Taklim melakukan penguatan pendidikan karakter pada jamaahnya.

Penelitian ini membahas Majelis Taklim Shirotol Mustaqim dalam mengedukasi jamaah dengan memperkuat pendidikan karakter dengan konsep "Profesional-Religius" sebagai salah satu upaya implementasi PMA No. 29 tahun 2019 tentang Majelis Taklim. Penelitian ini akan menjawab permasalahan utama yaitu bagaimana implementasi penguatan pendidikan karakter yang menekankan pada profesionalitas dan religiositas sebagai sebuah respons terhadap PMA No. 29 tahun 2019 tentang Majelis Taklim pada Majelis Taklim Shirotol Mustaqim Kota Semarang, dengan beberapa pertanyaan khusus (minor research question) yaitu : a) Bagaimana pengembangan pendidikan karakter profesional-religius Majelis Taklim Shirothol Mustaqim Kota Semarang ?, b) Apa faktor yang mempengaruhi keberhasilan penguatan pendidikan karakter profesional-religius bagi 
jamaah Majelis Taklim Shirotol Mustaqim?, c) Bagaimana nilai-nilai profesional-religius berdampak pada karakter jamaah Majelis Taklim Shirotol Mustaqim?, d) Bagaimana Majelis Taklim Shirotol Mustaqim dalam mengimplementasikan PMA No. 29 Tahun 2019 tentang Majelis Taklim ?.

\section{KAJIAN TEORI}

Kata character berasal dari bahasa Yunani charassein, yang berarti to engrave (melukis, menggambar), seperti orang yang melukis kertas, memahat batu atau metal. Berakar dari pengertian yang seperti itu, character kemudian diartikan sebagai tanda atau ciri yang khusus, dan karenanya melahirkan sutu pandangan bahwa karakter adalah 'pola perilaku yang bersifat individual, keadaan moral seseorang (Sudrajat, 2011). Karakter yang baik berkaitan dengan mengetahui yang baik (knowing the good), mencintai yang baik (loving the good), dan melakukan yang baik (acting the good). Ketiga ideal ini satu sama lain sangat berkaitan dalam membentuk karakter suatu masyarakat atau bangsa.

Eksistensi suatu bangsa sangat ditentukan oleh karakter yang dimiliki. Hanya bangsa yang memiliki karakter kuat yang mampu menjadikan dirinya sebagai bangsa yang bermartabat dan disegani oleh bangsabangsa lain. Pendidikan karakter seharusnya membawa jamaah ke pengenalan nilai secara kognitif, penghayatan nilai secara afektif, dan akhirnya ke pengamalan nilai secara nyata. Inilah rancangan pendidikan karakter (moral) yang oleh Thomas Lickona disebut moral knowing, moral feeling, dan moral action (Muchtar \& Suryani, 2019a). Pembentukan karakter pada intinya bertujuan membentuk bangsa yang tangguh, kompetitif, berakhlak mulia, bermoral, toleran, bergotong royong dan berjiwa patriotik (Andrias, 2018a).

Pendidikan karakter adalah sebuah sistem untuk mengembangkan nilai-nilai karakter siswa yang meliputi komponen pengetahuan, kesadaran atau kemauan, dan tindakan untuk diimplementasikan ke dalam agama, diri sendiri, masyarakat umum, lingkungan, dan bangsa sebagai manusia yang paripurna. Dalam pelaksanaan pendidikan karakter, setiap stakeholder pembelajaran harus terlibat dalam proses tersebut, termasuk komponen pendidikan, yaitu kurikulum, pembelajaran dan proses evaluasi, kualitas hubungan, penanganan pelajaran atau manajemen, manajemen sekolah, pelaksanaan kegiatan kokurikuler, penggunaan fasilitas, pendanaan, dan kinerja dari setiap dan semua komponen sekolah (Saridudin, 2021).

Beberapa penelitian terkait pengutan karakter di lembaga pendidikan banyak dilakukan, antara lain Achmad Dahlan Muchta dan Aisyah Suryani, dengan judul "Pendidikan Karakter Menurut Kemendikbud (Telaah Pemikiran atas Kemendikbud)". Dalam studi ini dijelaskan bahwa pendidikan karakter adalah suatu sistem pendidikan dengan penanaman nilai-nilai sesuai dengan budaya bangsa dengan komponen aspek pengetahuan (cognitive), sikap perasaan (affection felling), dan tindakan, baik terhadap Tuhan Yang Mahaesa (YME) baik untuk diri sendiri, masyarakan dan bangsanya. Dalam Kebijakan Nasional Pembangunan Karakter Bangsa Tahun 2010-2025 ditegaskan bahwa karakter merupakan hasil keterpaduan empat bagian, yakni olah hati, olah pikir, olah raga, serta olah rasa dan karsa.(Muchtar \& Suryani, 2019b).

Moh. Ahsanulkhaq dalam penelitianya "Membentuk Karakter Religius Peserta Didik Melalui Metode Pembiasaan". Ahsanulkhaq melakukan penelitian di SMPN 2 Bae Kudus. Hasil penelitian mengungkapkan bahwa upaya guru PAI dalam membentuk karakter religius ialah melalui metode pembiasaan yang diterapkan diantaranya berupa pembiasaan Senyum, Salam, dan Salim (3S), pembiasaan hidup bersih dan sehat, pembiasaan membaca doa harian (asma'ul husna), pembiasaan bersikap jujur, pembiasaan memiliki sikap tanggungjawab, Pembiasaan bersikap disiplin, pembiasaan ibadah, dan pembiasaan membaca Al-Qur'an (Ahsanulkhaq, 2019).

Dian Popi Oktari dan Aceng Kosasih dalam penelitiannya "Pendidikan Karakter Religius dan Mandiri di Pesantren". Dian dan Aceng melakukan penelitian di pesantren Manarul Huda Bandung. Hasil penelitian menyatakan bahwa karakter religius ditanamkan melalui rutinitas sehari-hari santrinya dimulai sejak bangun tidur hingga menjelang tidur. Pesantren ini juga memiliki 
program-program keahlian seperti

kewirausahaan, pertanian, dan peternakan sebagai upaya mengembangkan karakter kemandirian para santri.(Oktari \& Kosasih, 2019).

Isa Anshori dalam tulisannya "Penguatan Pendidikan Karakter di Madrasah." Pendidikan karakter di Madrasah diperkuat melalui harmonisasi olah hati (etik), olah rasa (estetik), olah pikir (literasi), dan olah raga (kinestetik); dengan dukungan pelibatan publik dan kerja sama antara madrasah, keluarga, dan masyarakat. Nilai-nilai karakter yang ditanamkan melalui gerakan PPK adalah nilai religius, nasionalis, mandiri, gotong royong dan integritas. Urgensi dari PPK ini adalah untuk membangun Sumber Daya Manusia yang merupakan pondasi pembangunan bangsa. Generasi yang diharapkan bisa dimunculkan adalah Generasi Emas, memiliki kualitas karakter, literasi dasar dan kompetensi 4C (Critical thinking, Creativity, communication, and Collaboration). Hal itu bisa dilakukan dengan cara membekali peserta didik menghadapi kondisi kemerosotan moral, etika, dan budi pekerti.(Anshori, 2017).

Pasmah Chandra, Nelly Marhayati dan Wahyu dengan jdul "Pendidikan Karakter Religius Dan Toleransi Pada Santri Pondok Pesantren Al Hasanah Bengkulu." Studi tersebut menyatakan bahwa pendidikan karakter religius dan toleransi santri di Pondok Pesantren Al Hasanah yang diterapkan melalui pembiasaan sebagai berikut, (1) Siswa shalat berjamaah di masjid, semua santri diwajibkan sholat fardhu di masjid, dan apabila tidak mengerjakan sholat akan mendapatkan hukunman. (2) santri berdzikir dan berdo'a setelah sholat. (3) santri berpuasa sunnah senin dan kamis (4) Siswa mengantri ketika berwudhu, siswa kelas $\mathrm{V}$ jika berwudhu mengantri namun kadangkali beberapa siswa kelas V kurang tertib, (5) santri membaca, menghafal, dan muroja'ah Al-Qur'an. (6) Santri mengadakan kegiatan muhadhoroh dan kultum. (7) Siswa menerapakan senyum, sapa, salam apabila bertemu ustad, atapun sesame santri. (8) Siswa berani ditunjuk untuk mengumandangkan adzan, sebagian besar siswa berani ditunjuk adzan bahkan berani menjadi imam, namun beberapa siswa ada yang tidak berani karena malu, (10) santri menerima pembelajaran Aqidah Akhlak mengenai karakter religius dan Toleransi (Chandra et al., 2020).

Arinah Fransori, Endang Sulistijani, dan Friza Youlinda Parwis dalam penelitiannya "Penyuluhan Pola Asuh Orang Tua Terhadap Anak Dalam Penguatan Pendidikan Karakter Anak Dan Literasi Digital Pada Ibu-Ibu Majelis Taklim Al-Hidayah Depok." Hasil kajian mengungkapkan bahwa pola asuh pada anak generasi milenial tidak bisa lepas dari perkembangan teknologi digital. Orang tua harus melek teknologi. Dengan pola asuh demokrasi terjalin adanya kerja sama orang tua dalam menguatkan pendidikan karakter yang berkaitan dengan kuatnya nilai akhlak atau moral pada anak. Mendidik anak di era digital dengan cara menerapkan pola asuh yang tidak otoriter karena anak tidak senang dipaksa melainkan dibujuk dan cenderung dibiarkan, tetapi juga harus tetap diawasi oleh orang tua. Selain itu, orang tua juga harus mampu memahami ragam aplikasi yang mendidik anak dan memandu anak untuk memainkannya dengan baik serta mengawasi penggunaan media informasi tersebut agar hal-hal negatif yang merusak pendidikan karakter anak dapat dicegah. Dengan adanya abdimas dari Universitas Indraprasta PGRI, diharapkan dapat semakin tumbuh nilai-nilai pendidikan karakter di setiap lingkungan masyarakat dan semakin menguatkan kehidupan berbangsa dan bernegara (Fransori et al., 2019).

Andrias Nurkamil Albusthomi, dengan judul "Pendidikan Akhlak Sebagai Landasan Pembentukan Karakter Di Majelis Taklim Konversi Diniyah (MTKD) Al Ikhlas Kec. Bandung Kulon". Hasil studi menunjukkan bahwa penerapan konsep pendidikan akhlak sebagai landasan di Majelis Taklim Konversi Diniyah Al-Ikhlas Kecamatan Bandung Kulon dengan beberapa cara untuk membentuk dan membina akhlak mulia diantaranya melalui: 1) Pendidikan Iman sebagai asas akhlak. 2) Pendidikan merupakan salah satu cara untuk mencorak manusia menjadi seseorang yang beriman. 3) Melalui latihan dan bimbingan pendidik berkualiti. 4) Mengikuti Rasulullah saw sebagai contoh (Uswah).(Andrias, 2018b). 
Firdiyanti Al Ma'idha, Elin Farichatul Jannah dan Imamul Arifin dalam penelitian dengan judul "Majelis Taklim Online Sebagai Wadah Pendidikan Dan Penguatan Karakter Mahasiswi Politeknik Elektronika Negeri Surabaya." Hasil penelitian mengungkapkan bahwa Majelis Taklim bukan semata-mata berhubungan dengan aspek religius saja, tetapi terkait pula dengan aspek sosial, pendidikan dan politik. Kajian memiliki peran sebagai wadah untuk membina dan mengembangkan kehidupan beragama dalam rangka membentuk pribadi yang berakhlakul karimah seperti berkaitan dengan pendidikan dan penguatan karakter mahasiswi Politeknik Elektronika Negeri Surabaya. Majelis Taklim merupakan salah satu bentuk character building. Sebagai upaya untuk membangun dan membentuk akhlak dan budi pekerti seseorang menjadi baik sehingga memiliki peran penting dalam membentuk karakter seseorang sesuai dengan syariat agama Islam (Al Ma'idha et al., 2021).

Nurmawati, Hafsah dan Arlina dalam studinya "Kontribusi Majelis Ta'lim Dalam Menanamkan Nilai-Nilai Pendidikan Karakter Terhadap Remaja Mesjid Desa Cinta Rakyat Kec. Percut Sei Tuan" mengungkapkan bahwa majelis ta'lim remaja mesjid di Cinta Rakyat telah memberi kontribusi terhadap penanaman nilai-nilai pendidikan karakter bagi remaja. Keterlibatan pihak pemerintahan Desa dan kepedulian masyarakat dan tokoh agama Cinta Rakyat dalam mengontrol berbagai kegiatan remaja mesjid telah memberi kontribusi terhadap penanaman nilai-nilai pendidikan karakter remaja, namun belum sepenuhnya dapat diberdayakan.(Nurmawati, 2016).

Religiusitas dianggap sebagai suatu hal yang sangat penting. Keberagamaan atau religius dapat diartikan sebagai bagian atau segi yang hadir dan terasa dalam pikiran dan dapat diuji melalui introspeksi atau dapat juga dikatakan sebagai aspek moral dan aktivitas keagamaan (Ancok, 1995). Keagamaan adalah pengalaman agama (religious experience), unsur perasaan dalam kesadaran beragama yaitu perasaan yang membawa pada keyakinan yang dihasilkan oleh tindakan (Darajat, 1993).

Keberagamaan atau religius lebih melihat aspek yang "di dalam lubuk hati nurani" pribadi, sikap personal yang sedikit banyak mengandung misteri bagi orang lain, karena bernafaskan keintimanan jiwa, cita rasa yang mencakup totalitas (termasuk rasio dan rasa manusiawinya) ke dalam pribadi manusia.

Internalisasi religius dapat direalisasikan dengan menciptakan suasana seluruh anggota keluarga merasakan kenyamanan dan kedamaian dan selalu merasakan kedekatan dengan yang Ilaahi Robbi dalam menjalani kehidupan. Internalisasi keberagamaan atau religius tersebut harus dapat diwujudkan dalam berbagai sisi kehidupan manusia. Aktivitas beragama tidak hanya terjadi ketika seseorang melakukan perilaku ritual/ibadah, tetapi juga ketika melakukan aktivitas lain yang didorong oleh kekuatan supranatural. Bukan hanya berkaitan dengan aktivitas yang tampak dan dapat dilihat oleh mata, tetapi juga aktivitas yang tidak tampak yang terjadi dalam diri seseorang (Hasan, 2017).

Beberapa penelitian di atas secara umum mengkaji pentingnya pendidikan karakter di lembaga pendidikan, seperti sekolah, madrasah, pesantren dan majelis taklim. Apabila dipetakan, model-model penguatan pendidikan karakter, terutama karakter religious dan akhlak mulia terbagi menjadi tiga pola, pertama, penanaman pendidikan karakter baik religious ataupun yang lainnya membutuhkan habituasi, kebiasaan dan rutinitas yang terpola, kedua, pendidikan karakter dalam implementasinya membutuhkan kerjasama dari berbagai unsur baik lembaga pendidikan, masyarakat dan orang tua, Ketiga, pendidikan karakter membutuhkan media yang tepat dalam implementasinya.

Penelitian ini mengkaji dan menguatkan penelitian sebelumnya dengan fokus bagaimana Majelis Taklim melakukan fungsi penguatan karakter pada aspek profesionalitas dan religiusitas bagi jamaahnya. Penguatan karakter yang selama ini identik dengan lembaga pendidikan seperti sekolah, madrasah atau pesantren ternyata dilakukan juga oleh Majelis Taklim Shirotol Mustaqim. Majelis Taklim yang selama ini berfungsi sebagai media dakwah dan pendidikan agama, saat ini 
bisa berfungsi sebagai penguat pendidikan karakter bagi para jamaahnya dalam aspek professionalitas dan religiusitas.

Majelis Taklim Shirotol Mustaqim yang berada di bawah naungan LDII Kota Semarang ini melakukan penguatan karakter profesionalreligius bagi jamaahnya. Profesional dalam kajian disini ialah mempunyai keahlian (skill) serta hidup mandiri dalam kehidupan bermasyarakat. Sedangkan religius ialah memiliki akhlak al karimah serta memahami Agama Islam dengan baik. Dalam melakukan edukasi kepada jamaah, Majelis Taklim Shirothol Mustaqim juga mengembangkan konsep Tri Sukses Pembinaan Penerus yaitu 1) Faham agama (aalim), 2) akhlakul karimah dan 3) mandiri.

Profesional-religius adalah karakter yang dikembangkan yang merupakan kemampuan dasar yang menyangkut kemampuan untuk menjalankan tugasnya secara profesional, dalam arti mampu membuat keputusan, keahlian atas beragamnya kasus serta mampu mempertanggungjawabkan berdasarkan teori dan wawasan keahliannya dalam perspektif Islam. Kompetensi profesional meliputi: 1) Mengetahui hal-hal yang perlu diajarkan, sehingga ia harus belajar dan mencari informasi tentang materi yang diajarkan, 2) Menguasai seluruh bahan materi, 3) Mengamalkan terlebih dahulu informasi yang telah didapat sebelum diajarkan, 4) Mempunyai kemampuan untuk menganalisis materi, 5) Mengevaluasi proses dari basil pendidikan, 6) Memberikan Uswatun Hasanah.

\section{METODOLOGI}

Penelitian ini menggunakan metode penelitian kualitatif yang datanya berupa uraian tertulis, uraian yang diperoleh dari informan, dan perilaku subjek yang diamati. Penelitian ini menunjuk pada prosedur penelitian yang menghasilkan data deskriptif, yakni apa yang dilakukan secara fundamental dan dituturkan informan, baik lisan maupun tulisan. Penetapan subjek penelitian atau responden sebagai informan, dipilih secara purposive atau dengan pertimbangan, kemampuan informan dalam menyampaikan informasi yang dibutuhkan oleh peneliti di lapangan. Informan yang dipilih berdasarkan pertimbangan tersebut, diharapkan dapat memenuhi kriteria informasi tentang permasalahan yang diteliti. Dalam penelitian ini yang dijadikan subjek penelitian adalah Majelis Taklim Shirotol Mustaqim Kota Semarang beserta seluruh pengurusnya.

Wawancara dalam penelitian ini dilakukan pada Pimpinan Majelis Taklim Shirotol Mustaqim Bapak Indarwanto dan pihak-pihak lain yang berhubungan seperti pengurus, ustaz, Pejabat Kantor Kementerian Agama Kota Semarang, penyuluh di Kota Semarang dan pengurus LDII Kota Semarang. Pengumpulan data dilakukan melalui observasi, wawancara dan studi dokumen. Observasi yang dilakukan dalam penelitian ini adalah observasi non partisipan atau partisipasi pasif, observasi non partisipan adalah suatu prosedur yang dilakukan oleh peneliti dengan mengamati tingkah laku guru dan peserta didik dalam keadaan alamiah, tetapi peneliti tidak melakukan partisipasi terhadap kegiatan di lingkungan yang diamati, artinya peneliti bertindak hanya sebagai pengamat, tidak ikut terlibat dalam kegiatan tersebut. Dokumentasi merupakan suatu teknik pengumpulan data dengan menghimpun dan menganalisis dokumen-dokumen berupa catatan peristiwa yang sudah berlalu dapat berupa tulisan, gambar atau karya non monumental dari guru dan peserta didik yang berhubungan dengan sekolah.

Peneliti melakukan analisis dengan mereduksi data yakni merangkum semua hasil wawancara, observasi dan telaah dokumentasi kemudian memilih dan mengambil hal pokok, yang difokuskan pada permasalahan yang ingin dikaji peneliti yakni berdasarkan indikator-indikator yang dikembangkan terkait dengan implementasi PMA No. 29 tentang Majelis Taklim dan penguatan karakter melalui konsep Profesional-Religius yang dikembangkan Majelis Taklim Shirotol Mustaqim Kota Semarang.

Setelah data diperoleh peneliti di lokasi penelitian, kemudian dipilih dan dipilah halhal pokok yang difokuskan pada permasalahan yang ingin dikaji, langkah selanjutnya yaitu peneliti menyajikan data 
tersebut dalam bentuk narasi, artinya setiap fenomena yang terjadi apa pun ditemukan, peneliti menarasikan dan memberikan interpretasi terhadap fenomena-fenomena tersebut. Hal ini dilakukan untuk memberikan pemahaman kepada peneliti dengan fenomena-fenomena yang terjadi. Setelah hal ini ditempuh, maka peneliti merencanakan tindakan apa selanjutnya yang harus diambil berdasarkan pemaknaan fenomena-fenomena tersebut. Kesimpulan awal yang ditemukan dapat bersifat sementara sehingga masih dapat berubah jika tidak didukung oleh bukti yang kuat. Jika bukti-bukti yang diperoleh telah kuat maka penelitian dianggap kredibel.

\section{HASIL DAN PEMBAHASAN}

Majelis Taklim Shirothol Mustaqim didirikan pada tahun 1983 oleh para tokoh LDII pada waktu itu yaitu H. Suwoko, H. Suyono, H. Agus Wafdullah, dan H. Sunardi. Pendirian Majelis Taklim ini dilatarbelakangi oleh pemikiran bahwa warga sangat membutuhkan pendidikan keagamaan yang belum banyak tersedia di Kelurahan Manyaran khususnya jamaah LDII. Pada tahun 1970 kondisi kampung Manyaran masih sepi dan untuk mencegah kerawanan yang mungkin terjadi, para tokoh berinisiatif mendirikan Majelis Taklim. Majelis Taklim ini mendapatkan simpati dari warga sekitar sehingga jamaah pun terus bertambah. Maka untuk memfasilitasi kebutuhan jamaah yang ingin memondokkan anaknya, kemudian dibangun pula Pesantren Shirothol Mustaqim. Majelis Taklim Shirothol Mustaqim beralamat di Jl. Gedongsongo III No.10 Kel. Manyaran Kota Semarang dengan izin Operasional dari Kementerian Agama, di bawah pimpinan Ustaz Indarwanto. Selama ini beberapa Ustaz pengajar yang aktif antara lain Ustaz Daud A, Ustaz Agus Salim, Ustaz Sukadrina, Ustaz Maryono, Ustaz Iwan, Ustaz Ridwan, Ustaz Aditia, dan Ustaz Indarwanto. Majelis Taklim ini memiliki Jamaah tetap berkisar 100-300 orang, dengan waktu pengajian setiap Selasa dan Jumat (19.30-21.00 WIB).

Berdasarkan hasil wawancara dengan Ustaz Indarwanto, sebagai pimpinan Majelis Taklim ini, bahwa Majelis taklim Shirotol Mustaqim memiliki visi yaitu "menjadi organisasi dakwah Islam profesional yang mampu mewujudkan manusia Indonesia yang tekun beribadah kepada Allah SWT, memiliki sifat akhlakul karimah, memakmurkan bumi, dan membangun masyarakat madani yang kompetitif berbasis tabiat jujur, amanah, kerja keras dan hemat, rukun, kompak, dan kerja sama yang baik". Sedangkan misinya ialah "memberikan kontribusi nyata dalam pembangunan bangsa dan negara melalui dakwah, pengkajian, pemahaman dan penerapan ajaran Islam yang dilakukan secara menyeluruh, berkesinambungan, dan terintegrasi sesuai dengan peran, posisi, tanggung jawab profesi sebagai komponen bangsa dalam wadah Negara Kesatuan Republik Indonesia".

Hal ini juga sebagai wujud langkah baru LDII yang lebih terbuka. Sebagai wujud keterbukaan LDII Kota Semarang tampak pula dari sejumlah fasilitas pelayanan masyarakat yang didirikan, seperti Rumah Sakit Banyumanik, Pondok Pesantren Mahasiswa di Banyumanik dan Sampangan, Koperasi Syariah di Sendangmulyo, dan sejumlah masjid berikut kegiatan pengajian Al-Quran bagi jamaah usia dewasa dan anak-anak di sejumlah tempat di Kota Semarang. Majelis Taklim Shirotol Mustaqim siap berkontribusi dalam membangun Negara Kesatuan Republik Indonesia. LDII berkomitmen pada 4 (empat) pilar yaitu Pancasila, Bhineka Tunggal Ika, NKRI dan UUD 1945.

\section{Majelis Taklim dalam Penguatan Pendidikan Karakter Jamaah}

Dalam bidang pendidikan, Majelis Taklim Shirothol Mustaqim Kota Semarang berperan membina umat supaya hidup mandiri sehingga jamaahnya paham dan mumpuni dengan bekal pengetahuan agama yang cukup. Majelis Taklim Shirothol Mustaqim mengembangkan pendidikan karakter dengan konsep Profesional-Religius dalam mengedukasi jamaahnya. Yang dimaksud karakter profesional ialah mempunyai keahlian (skill) serta hidup mandiri dalam kehidupan bermasyarakat. Sedangkan karakter religius ialah memiliki akhlakul karimah serta memahami Agama Islam dengan baik dan benar. 
Dalam melakukan edukasi dan penguatan pendidikan karakter kepada jamaah, Majelis Taklim Shirothol Mustaqim mengembangkan konsep Tri Sukses Pembinaan Penerus yaitu 1) Faham agama (aalim), 2) akhlakul karimah dan 3) mandiri. Faham agama adalah memahami agama harus melalui proses belajar atau menuntut ilmu, karena di tangan orang-orang yang paham agama segala apa yang dia miliki seperti harta, pangkat, dan kedudukan serta kehidupan yang dia jalani akan bermakna dan mendatangkan kebaikan bagi dirinya, baik di dunia maupun di akhirat nanti. Fahamnya seseorang terhadap Islam sebagai tanda Allah menginginkan kebaikan pada dirinya, harus diikuti dengan amal saleh dan akhlak mulia. Islam sebagai rahmat bagi semesta alam tidak akan tampak apabila sebatas pemahaman, tapi harus terimplementasi dalam tindakan dan perbuatan.

Menurut pengurus, Akhlakul karimah ialah budi pekerti atau sebuah perangai yang mulia. Sebuah akhlak memiliki tujuan agar setiap orang bertingkah laku atau bertabiat sesuai dengan adat istiadatnya yang baik dan sesuai dengan ajaran agama Islam. Berbakti kepada orang tua, sopan terhadap guru, bersikap baik kepada saudara, berbuat baik kepada tetangganya, suka menolong kepada orang lain, cinta kepada Allah, melakukan perbuatan baik dan menjauhi larangan karena Allah, cinta dan taat kepada Rasul, menyayangi orang yang lemah, memelihara dan menyantuni binatang, memelihara dan menyantuni tumbuh-tumbuhan, menjaga amanah, menepati janji, sabar, pemaaf, pemurah, Ikhlas, hidup sederhana, Selalu bersyukur kepada Allah dan bertawakal merupakan akhlak karimah yang mesti dilakukan oleh seorang muslim. Sedangkan Kemandirian adalah sikap atau perilaku dan mental yang memungkinkan seseorang untuk bertindak bebas, benar, dan bermanfaat; berusaha melakukan segala sesuatu dengan jujur dan benar atas dorongan dirinya sendiri dan kemampuan mengatur diri sendiri, sesuai dengan hak dan kewajibannya, sehingga dapat menyelesaikan masalah-masalah yang dihadapinya; serta bertanggung jawab terhadap segala keputusan yang telah diambilnya melalui berbagai pertimbangan sebelumnya.
Di samping itu juga Majelis Taklim Shirothol Mustaqim mengembangkan 6 tabiat luhur yaitu :1) Rukun, 2) Kompak, 3) Kerja sama dengan baik, 4) Jujur, 5) Amanah, dan 6) Mujhid-Mushid (hidup kerja keras, tirakat banter dan hidup hemat). Majelis taklim shirotol Mustaqim mengajarkan hidup rukun ialah hidup damai dan tenteram saling toleransi antara masyarakat yang beragama sama maupun berbeda, kesediaan mereka untuk menerima adanya perbedaan keyakinan dengan orang atau kelompok lain, membiarkan orang lain untuk mengamalkan ajaran yang diyakini oleh masing-masing masyarakat, dan kemampuan untuk menerima perbedaan. Sungguhpun masyarakat berbeda agama, ras, etnis, tradisi, dan budaya namun melalui keragaman ini dapat dibangun suatu tatanan hidup yang rukun damai dan tercipta kebersamaan hidup serta toleransi yang dinamis dalam membangun bangsa Indonesia. Kerukunan berarti sepakat dalam perbedaan-perbedaan yang ada dan menjadikan perbedaan-perbedaan itu sebagai titik tolak untuk membina kehidupan sosial yang saling pengertian serta menerima dengan ketulusan hati yang penuh keikhlasan.

Kekompakan dan persatuan adalah kunci untuk keberhasilan mencapai tujuan yang dicita-citakan. Dengan kompak kita dapat mengatasi segala intrik, ancaman, tantangan, hambatan, maupun gangguan yang datang kepada kita. Kerja sama di kalangan jamaah akan memberikan kemanfaatan dan keuntungan yang lebih dibandingkan dengan dilakukan secara sendirian. Networking akan bisa ditumbuhkan secara lebih luas, lebih menyeluruh, dan lebih efisien. Akan tetapi, kerja sama (musyarakah) itu bisa dibangun dengan kokoh dan menghasilkan keuntungan lebih, jika dilandasi dengan keinginan kuat untuk saling menjunjung tinggi amanat kebersamaan dan menjauhi pengkhianatan.

Tabiat berikutnya yang dikembangkan oleh Majelis Taklim Shirotol Mustaqim adalah kejujuran. Jujur atau dalam bahasa arab dikenal dengan istilah ash shidqu atau shiddiq, yang memiliki arti nyata atau berkata benar. Artinya, jamaah harus menampilkan bentuk kesesuaian antara ucapan dan perbuatan atau antara 
informasi dan kenyataan. Kejujuran berarti bebas dari kecurangan, mengikuti aturan yang berlaku dan kelurusan hati. Banyak sekali bentuk kejujuran dalam kehidupan kita seharihari. Sejak kecil kita pasti telah diajarkan oleh orang tua kita untuk selalu berbuat jujur dan tidak berbohong. Hal ini tentu sesuai dengan ajaran agama Islam yang telah dicontohnya Rasulullah Shallallahu 'Alaihi Wa Sallam.

Jamaah juga diajarkan bagaimana bersikap amanah dalam kehidupan. Amanah adalah segala sesuatu yang harus dipertanggungjawabkan dan berkaitan dengan orang lain atau pihak lain. Amanah bisa berupa benda, pekerjaan, perkataan, ataupun kepercayaan. Maka, amanah bisa berbentuk apa saja yang nantinya akan dimintai pertanggungjawabannya. Kemampuan seseorang menjaga amanah merupakan tolak ukur akan usahanya menjalankan perintah Allah SWT dan menjauhi larangannya. Tidak hanya untuk segi ibadah, seseorang yang bersifat amanah juga akan memiliki hubungan yang baik dengan manusia lainnya. Dia akan menjadi bisa dipercaya dan dihormati oleh orang-orang di sekitarnya.

Terakhir, yang termasuk tabiat luhur yang dikembangkan Majelis Taklim Shirotol Mustaqim adalah hidup kerja keras, tirakat banter dan hidup hemat (Mujhid-Mushid). Kerja keras merupakan sebuah perbuatan yang mulia. Kerja keras bisa bermakna seseorang melakukan sesuatu dengan sungguh-sungguh untuk bisa mendapatkan apa yang dia inginkan. Tujuan yang ingin dicapai dari kerja keras bisa berbagai macam. Bisa dengan tujuan mencari rezeki, belajar, berkarya, karier, dan lain sebagainya. Kerja keras seseorang dalam bekerja pun ternyata juga merupakan bentuk keimanannya kepada Allah SWT, dan harus ingat bahwa tujuan hidup di dunia adalah untuk mencari rida Allah SWT. Maka, jika kita mengingat hal tersebut, kita akan bisa meluruskan niat kita dalam bekerja dan melakukan kegiatan apa pun dengan niat ibadah mencari rida-Nya.

Paparan di atas memberikan gambaran bahwa Majelis Taklim Shirotol Mustaqim Kota Semarang melakukan edukasi dan penguatan karakter pada jamaahnya, terutama karakter religius dan kemandirian agar jamaah tidak hanya sukses di dunia tapi juga di akhirat, maka yang ditekankan pada jamaah bukan hanya urusan yang berkaitan dengan ukhrawi saja, tetapi segala hal yang berkaitan dengan urusan duniawi. Hal itu perlu dilaksanakan dan dimiliki jamaah secara seimbang, agar kehidupan menjadi lebih bermakna tidak hanya untuk diri sendiri tetapi juga untuk masyarakat banyak.

\section{Faktor Berpengaruh Pada Implementasi Karakter Profesional-Religius}

Paradigma baru yang dikembangkan Majelis Taklim Shirothol Mustaqim sebagai lembaga pendidikan non-formal yang berada di bawah naungan LDII dipengaruhi beberapa hal antara lain sikap terbuka para tokoh LDII yang menerima berbagai kalangan; keterlibatan para tokoh LDII Kota Semarang dalam beberapa organisasi seperti MUI, FKUB dan Dispora Kota Semarang dan juga kurikulum yang dikembangkan. Keterbukaan Majelis Taklim Shirotol Mustaqim kota Semarang pada seluruh kalangan masyarakat tidak terlepas dari peran para tokoh LDII dalam membina umat yang menekankan Islam rahmatan lil alamiin. Hal itu dapat dilihat dari peningkatan jamaah yang selalu mengalami peningkatan, untuk tahun 2020 ini diperkirakan ada sekitar 300 jamaah, tahun 2019 diperkirakan hanya 200 jamaah. LDII mempunyai komitmen yang kuat untuk menjaga kerukunan umat beragama, baik pada internal umat beragama, antar umat beragama dan juga umat beragama dengan pemerintah. Komitmen untuk menjaga kerukunan umat beragama itu tidak hanya sekedar slogan dan retorika indah, melainkan diwujudkan dalam tindakan nyata. Dengan sesama ormas Islam, LDII selalu menjaga tali silaturahmi dengan bersama-sama melakukan aktivitas dakwah dalam rangka membina umat (Lubis, 2020).

Indikator keterbukaan menurut Aditya Nurullahi Purnama dan Singgih Tri Sulistiyono bisa tercermin dari diversifikasi kegiatan dakwah yang dilakukan oleh anggotanya, aktivitas dakwah mereka tidak hanya berfokus pada dakwah agama, tetapi juga dakwah sosial di masyarakat. Misalnya, sejak tahun 2000 LDII Kota Semarang mengambil peranan untuk menyelesaikan permasalahan masyarakat di bidang kesehatan dengan membuka Rumah 
Sakit Banyumanik setelah dibeli sebelumnya melalui Yayasan Nurul Aini milik LDII. Pada bidang pendidikan, LDII Kota Semarang membuka Pondok Pesantren Mahasiswa Bina Khoirul Insan yang berawal dari rumah indekos sederhana di Jalan Ngesrep Timur V No.8 Sumurboto Banyumanik Semarang Banyumanik pada 2007. LDII Kota Semarang juga ikut mengambil peran dalam kegiatan ekonomi masyarakat Semarang salah satunya dengan mendirikan koperasi syariah Wali Barokah Mandiri pada 2016. Eksistensi dari ketiga institusi LDII ini bisa dipandang sebagai upaya LDII untuk memberikan kontribusi dan manfaat bagi masyarakat (Purnama \& Sulistiyono, 2020).

Di samping keterbukaan, faktor lain ialah keterlibatan para tokoh LDII kota Semarang dalam berbagai organisasi seperti MUI, FKUB dan Dikpora Kota Semarang. Beberapa tokoh LDII tersebut adalah Yenuarso pengurus MUI Kota Semarang, Sholihul Hadi pengurus FKUB Kota Semarang dan Sunindyo Ketua Dispora Kota Semarang yang sekaligus juga Ketua LDII Kota Semarang. Sebelumnya ada Dono Raharjo yang menjadi Hakim Ad Hoc di Bengkulu, yang pernah aktif juga di Dispora Kota Semarang. Hal itu sebagai implementasi paradigma LDII yang terbuka dan komitmen pada NKRI. Dengan paradigma baru LDII yang bersifat terbuka, saat ini banyak tokoh LDII kota Semarang banyak yang terlibat aktif dalam berbagai organisasi. Hal ini menjadikan LDII sekarang lebih terbuka. Hal itu dilakukan untuk menuding sebagian masyarakat yang menganggap LDII bersifat eksklusif dan tertutup. Di samping itu juga LDII terbuka terhadap undangan dan acara-acara yang dilakukan oleh pemerintah ataupun anggota masyarakat. Para tokoh LDII hadir pada acaraacara yang menuntut kehadiran mereka.

Faktor lainnya ialah kurikulum dan pembelajaran di Majelis Taklim Shirotol Mustaqim diarahkan pada bagaimana jamaah memiliki pemahaman yang luas dan toleran serta terbuka. Materi pembelajaran yang diajarkan di Majelis Taklim ialah berkisar pada pembelajaran Al-Quran dan Hadis. Sedangkan kitabnya ialah Kitab Ahkam dan Kutubus Sittah ialah Shohih Bukhori, Shohih Muslim, Sunan Abu Daud, Jami'u at-Turmudzi/Sunan
at-Turmudzi, Sunan an-Nasa'i dan Sunan Ibnu Majah. Selain itu juga diajarkan Akidah, Akhlak, fiqih dan lainnya yang bersumber dari diktat, modul dan buku. Pembelajaran diajarkan oleh ustaz yang sudah punya ijazah dari Pondok Pusat LDII di Kediri, dengan persyaratan bahwa ustaz tersebut harus sudah mengkaji Al-Quran 30 Juz, dan menguasai minimal 1 kitab dari Kutubus Sittah.

Kurikulum Majelis Taklim Shirotol Mustaqim menekankan dalam pembinaan keimanan dan peningkatan wawasan agama para jamaah. Karena kurikulum tidak hanya berisikan pengetahuan ilmiah berupa daftar mata pelajaran semata tetapi juga pengalaman (Saridudin, 2020). Hal itulah yang dipahami oleh pengurus majelis taklim, sehingga kurikulum dikembangkan secara lebih luas. Pengajian ibu-ibu Majelis Taklim Shirotol Mustaqim yang merupakan warga LDII sangat besar manfaatnya dalam rangka menambah wawasan keagamaan dan juga wawasan kebangsaan. Pengajian ini dikelola dengan baik dan disiplin, sehingga bagi ibu-ibu warga LDII Semarang memiliki kewajiban untuk aktif di dalamnya. Setiap kali pengajian diisi dengan materi yang sudah disusun sedemikian rupa, terjadwal dengan kurikulum yang jelas, dan diisi oleh narasumber yang ahli dalam bidangnya masing-masing. Berbagai materi yang disampaikan dalam pengajian ini, mulai dari masalah ibadah, akhlak bermasyarakat, adab menuntut ilmu, hingga tata cara mendapatkan nafkah yang halal.

\section{Dampak Pengembangan Karakter Profesional-Religius pada Karakter Jamaah}

Sikap profesional-religius yang dikembangkan Majelis Taklim Shirothol Mustaqim berdampak pada karakter jamaah yaitu bersikap moderat, toleran dan humanis, serta tumbuhnya sikap kebangsaan di kalangan jamaah. Sikap moderat dipraktikkan jamaah dengan menerima berbagai kalangan secara terbuka. Jamaah Majelis Taklim Shirotol Mustaqim bergaul dan berinteraksi dengan masyarakat atau jamaah lainnya tanpa memandang atau membedakan antara satu dengan lainnya. Salah contoh misalnya ketika pembagian daging kurban pada Hari Raya Idul Adha, jamaah berbagi daging tersebut dengan semua kalangan di luar LDII tanpa membeda- 
bedakan. Karena menurut pengurus majelis taklim, untuk menjadikan Islam moderat, perlu memperkuat akidah, akhlakul karimah, membangun kerja sama dan toleransi.

Sikap toleran yang dikembangkan Majelis Taklim Shirothol Mustaqim sejalan dengan konsep tasamuh yang berisi tindakan tuntutan dan penerimaan dalam batas-batas tertentu, karena perilaku tasamuh dalam beragama memiliki pengertian untuk tidak saling melanggar batasan, terutama yang berkaitan dengan batasan keimanan (Aqidah)(Ghazali, 2016). Sikap toleran yang dikembangkan ialah penerimaan jamaah atas semua kalangan dari berbagai unsur, golongan dan latar belakang. Jamaah majelis Taklim Shirotol Mustaqim terbuka kepada siapa saja yang mau belajar ilmu agama atau untuk membangun silaturahmi antar warga Negara. Hal ini sebagai wujud penerapan sikap toleransi jamaah kepada semua kalangan. Toleransi bisa menunjukkan seberapa besar rasa nasionalisme seseorang. Karena orang yang memiliki toleransi tinggi, biasanya akan memiliki rasa cinta yang tinggi pula terhadap tanah airnya. Sebab ia menyadari bahwa Indonesia adalah negara majemuk yang memiliki banyak perbedaan. Dengan sikap toleransi, setiap orang menghargai yang lainnya dan memberikan rasa kasih sayang yang sama terhadap setiap perbedaan. Dengan begitu, rasa persaudaraan sebangsa dan setanah air pun akan semakin terpupuk. Dan setiap kelompok juga dapat terhindar dari berbagai jenis perpecahan.

Sikap kebangsaan yang dipraktikkan jamaah Majelis Taklim Shirotol Mustaqim ialah penyelenggaraan upacara bendera yang diselenggarakan setiap ada perayaan Hari-hari besar Keagamaan, atau dilaksanakan setiap tanggal 17 untuk tiap bulannya. Dengan menanamkan rasa sikap kebangsaan dan cinta tanah air terhadap nusa dan bangsa diharapkan terciptanya warga negara yang utuh secara sepenuh hati mencintai negaranya (Hubi \& Halimi, 2018). Hal ini dilakukan sebagai pengingat akan Hari Kemerdekaan Indonesia. Dengan demikian nasionalisme dalam paham jamaah merupakan suatu paham kesadaran untuk hidup bersama sebagai suatu bangsa, karena adanya kebersamaan kepentingan, rasa senasib seperjuangan dalam menghadapi masa lalu dan masa kini, serta kesamaan pandangan , harapan dan tujuan dalam merumuskan citacita masa depan bangsa.

Bagi jamaah Majelis Taklim yang merupakan warga LDII komitmen pada kesatuan bangsa dan ukhuwah Islamiyah menjadi bagian penting dalam perjuangan. Dalam mewujudkan komitmen kesatuan bangsa ini, maka LDII memakai asas Pancasila dengan pandangan bahwa bangsa ini adalah plural, maka Pancasila merupakan asas yang relevan bagi bangsa Indonesia. Sedangkan komitmen pada ukhuwah Islamiyah, LDII tidak hanya sebatas bermain retorika, melainkan diwujudkan dalam realitas di masyarakat. LDII menjalin hubungan baik dengan berbagai ormas Islam, seperti NU, Muhammadiyah, MUI, Al-Wasliyah dan lainlain. Berbagai kerja sama dijalin dengan baik dalam rangka meningkatkan kegiatan dakwah di tengah masyarakat.

Penjelasan di atas mencerminkan bahwa dakwah yang dilakukan di Majelis Taklim Shirotol Mustaqim memiliki model yang berbeda dengan Majelis Taklim yang lain, penekanan pada perlunya saling menghargai dalam upaya menguatkan kerukunan di tengah masyarakat. Komitmen menjaga kerukunan dan persatuan yang ditekankan pada jamaah harus dimiliki oleh semua jamaah Majelis Taklim dengan cara melakukan dialog agama secara kontinu. Sebab dengan dialog akan bisa mencegah terjadinya kecurigaan dan kebencian. Manajemen Majelis Taklim harus memperhatikan unsur-unsur perencanaan, pengorganisasian, penggerakan dan kontrol perlu dilakukan setiap majelis taklim, agar target yang diprogramkan bisa tercapai secara maksimal. Penguatan kerukunan haruslah mencakup internal umat beragama, antar umat beragama, dan antar umat beragama dengan pemerintah. Majelis Taklim Shirotol Mustaqim sebagai lembaga non-formal di bawah LDII Kota Semarang selalu berusaha memaksimalkan program dakwah pada semua kelompok masyarakat, agar pesan amar makruf nahi munkar bisa teraktualisasikan dengan baik. 


\section{Respons Majelis Taklim Terhadap PMA No.29 Tahun 2019}

Majelis Taklim Shirotol Mustaqim sebagai binaan dari LDII Kota Semarang dalam mengembangkan dakwah Islam mengalami perkembangan yang sangat pesat sebagaimana perkembangan LDII Kota Semarang. Sejak kehadirannya di Semarang pada 1970-an, LDII Kota Semarang aktif mengajarkan gagasan Islam mereka untuk kembali kepada Al-Quran dan Hadits. Sifat dan karakter awal LDII yang tertutup, telah menempatkan kelompok ini sebagai minoritas Islam. Akibatnya, eksistensi LDII mendapat penolakan dari arus utama Islam mayoritas. Namun, konteks zaman yang berubah, telah mendorong LDII Kota Semarang untuk menerapkan berbagai strategi baru, yang lebih terbuka. LDII Kota Semarang menerapkan dua strategi utama untuk perluasan dakwah, yaitu strategi kultural dan struktural. Strategi kultural LDII didukung oleh perangkat sosial yang disebut konsep budi luhur. Konsep budi luhur atau akhlakul karimah, yaitu sebuah perilaku yang menunjukkan kepribadian positif yang mewujud dalam sikap ramah, tenggang rasa, aktif membantu, serta teladan dalam bermasyarakat. Konsep ini membantu para jamaah LDII untuk memenangkan hati masyarakat, sehingga terdorong untuk bersikap simpatik atau setidaknya tidak menentang dakwah LDII di lingkungan mereka. Pendekatan dakwah secara struktural yang dilakukan sejak 1990, telah pula menempatkan LDII Kota Semarang mampu memperluas daya jangkau dakwah mereka di Kota Semarang. Kedua strategi itu terbukti efektif. Ketika pada masa-masa awal dianggap sebagai ancaman, pada masa-masa berikutnya, eksistensi LDII Kota Semarang telah berubah menjadi kekuatan baru yang layak diperhitungkan Aditya (Purnama \& Sulistiyono, 2020).

Majelis Taklim menurut PMA No. 29 tahun 2019 adalah lembaga atau kelompok masyarakat yang menyelenggarakan pendidikan keagamaan Islam non formal sebagai sarana dakwah Islam. Majelis Taklim adalah organisasi dakwah kemasyarakatan yang didirikan oleh masyarakat dengan tujuan menyampaikan ajaran agama Islam untuk dapat dipahami dan diamalkan oleh setiap orang Muslim dalam kehidupan mereka seharihari (Al Faruq, 2020). Lahirnya PMA Nomor 29 Tahun 2019 tentang Majelis Taklim mendapat respons luas dari publik ada yang sependapat ada juga yang tidak sependapat. Bagi yang tidak sependapat PMA ini adalah bentuk pengekangan terhadap Majelis Taklim karena harus mematuhi beberapa persyaratan administratif. Sedangkan menurut pemerintah PMA ini lahir sebagai respons atas kebutuhan data majelis taklim, yang penyusunannya melibatkan para pimpinan organisasi majelis taklim, di antaranya BKMT (Badan Kontak Majelis Taklim), FKMT (Forum Komunikasi Majelis Taklim), PMTI (Perhimpunan Majelis Taklim Indonesia), Permata (Pergerakan Majelis Taklim), Hidmat Muslimat NU, Fatayat, Aisyiyah Muhammadiyah, Nasyiatul Aisyiyah, para tokoh, dan praktisi majelis taklim.

Di Kota Semarang, setelah PMA ini terbit dan ditandatangani tanggal 12 November 2019, dalam catatan Kasie Bimas Islam Kantor Kementerian Agama Kota Semarang baru terdaftar 25 Majelis Taklim dan mendapatkan Surat Keterangan Terdaftar (SKT) dari Kementerian Agama. Belum ada Juknis yang lebih rinci terkait operasionalisasi dari PMA ini, sehingga dalam teknis di lapangan mengalami kendala apalagi terkait dengan Covid-19 yang sedang melanda Indonesia dan dunia sekarang ini. Banyak Majelis Taklim di Kota Semarang yang belum mengetahui secara pasti PMA Nomor 29 Tahun 2019 tentang Majelis Taklim ini. Problem sosialisasi menjadi maslah utama dalam implementasi PMA ini. Banyak majelis taklim yang belum bayak tahu secara rinci apa dan bagaimana isi dari PMA ini.

Berkaitan dengan PMA Nomor 29 Tahun 2019 tentang Majelis Taklim ini, pengurus Majelis Taklim Shirotol Mustaqim sebagai Majelis Taklim yang punya afiliasi terhadap LDII menganggap bahwa PMA ini sangat dibutuhkan karena pemerintah harus punya data yang valid supaya bisa melakukan pembinaan terhadap Majelis Taklim yang ada di Indonesia. Dalam kehidupan bernegara Majelis Taklim harus mengikuti instruksi dari pemerintah. PMA ini dibutuhkan agar progres kegiatan majelis taklim lebih terarah. Majelis 
Taklim Shirotol Mustaqim sendiri secara kelembagaan sudah terdaftar di Kementerian Agama, dan selalu melaporkan kegiatannya, walaupun belum sepenuhnya mengikuti aturan yang tertera dalam PMA No. 29. Kendala yang dihadapi terkait dengan implementasi PMA ini ialah masih belum jelasnya juknis yang lebih detail terkait proses pengajuan Surat Keterangan Terdaftar (SKT) kepada Kemenag, serta bentuk laporan yang harus disampaikan secara berkala setiap akhir tahun. Majelis Taklim Shirotol Mustaqim bermaksud mengadakan sosialisasi PMA ini kepada Majelis Taklim yang lain yang berada di bawah naungan LDII Kota Semarang yang berjumlah sekitar 60 Majelis Taklim, agar seluruh Majelis Taklim di bawah naungan LDII terdaftar di pemerintah.

Sebagai upaya penerimaan Majelis Taklim Shirotol Mustaqim terhadap PMA No. 29 tentang, majelis taklim memperkuat fungsinya sebagaimana pasal 2 dari PMA tersebut yaitu 1) pendidikan agama Islam bagi masyarakat; 2) pengaderan Ustaz dan/atau Ustazah, pengurus, dan jemaah; 3) penguatan silaturahmi; 4) pemberian konsultasi agama dan keagamaan; 5) pengembangan seni dan budaya Islam; 6) pendidikan berbasis pemberdayaan masyarakat; 7) pemberdayaan ekonomi umat; dan/atau 8) pencerahan umat dan kontrol sosial dalam kehidupan berbangsa dan bernegara.

Hal tersebut dilakukan sebagai upaya penguatan moderasi beragama di majelis taklim terutama dalam hal penyampaian materi oleh ustaz atau ustazah agar tidak bertentangan dengan Islam Rahmatan Lilaalamiin. Sikap moderat adalah pilihan untuk memiliki cara pandang, sikap, dan perilaku di tengah-tengah di antara pilihan ekstrem yang ada, sedangkan ekstremisme beragama adalah cara pandang, sikap, dan perilaku melebihi batas-batas moderasi dalam pemahaman dan praktik beragama. Karenanya, moderasi beragama harus bisa diimplementasikan oleh semua jamaah majelis taklim dalam cara pandang, sikap, dan perilaku selalu mengambil posisi di tengah-tengah, selalu bertindak adil, dan tidak ekstrem dalam beragama, apalagi terjebak dalam praktik radikalisme.

\section{PENUTUP}

Majelis Taklim Shirothol Mustaqim Kota Semarang berperan membina umat supaya memiliki karakter religius dan mandiri sehingga jamaahnya paham dan mumpuni dengan bekal pengetahuan agama yang cukup. Majelis Taklim Shirothol Mustaqim mengembangkan karakter Profesional-Religius dalam mengedukasi jamaahnya. Implikasi dari karakter Profesional, jamaah diharapkan mempunyai keahlian (skill) serta hidup mandiri dalam kehidupan bermasyarakat. Sehingga umat atau jamaah tidak bergantung kepada orang lain, atau bisa berdiri di atas kaki sendiri dalam mencukupi kebutuhannya. Sedangkan karakter religius berimplikasi pada jamaah yang memiliki akhlak al-karimah serta memahami Agama Islam dengan baik. Dalam melakukan edukasi kepada jamaah, Majelis Taklim Shirothol Mustaqim mengembangkan konsep Tri-Sukses Pembinaan Penerus yaitu Faham agama (aalim), akhlak al-karimah dan mandiri.

Paradigma baru yang dikembangkan Majelis Taklim Shirothol Mustaqim sebagai lembaga pendidikan non-formal yang berada di bawah naungan LDII dipengaruhi beberapa hal diantaranya sikap terbuka para tokoh LDII yang menerima berbagai kalangan; keterlibatan para tokoh LDII Kota Semarang dalam beberapa organisasi seperti MUI, FKUB dan Dispora Kota Semarang dan juga kurikulum yang dikembangkan. Sikap profesional-religius yang dikembangkan Majelis Taklim Shirothol Mustaqim berdampak pada karakter jamaah yaitu bersikap moderat, toleran dan humanis, serta tumbuhnya sikap kebangsaan di kalangan jamaah.

Berkaitan dengan implementasi PMA Nomor 29 Tahun 2019 tentang Majelis Taklim, Majelis Taklim Shirotol Mustaqim sebagai Majelis Taklim yang punya afiliasi terhadap LDII menganggap bahwa PMA ini sangat dibutuhkan karena pemerintah harus punya data yang valid supaya bisa melakukan pembinaan terhadap Majelis Taklim yang ada di Indonesia. PMA ini dibutuhkan agar progres kegiatan majelis taklim lebih terarah dan jelas. Majelis Taklim Shirotol Mustaqim sendiri, secara kelembagaan sudah terdaftar di Kementerian Agama, dan selalu melaporkan 
kegiatannya, walaupun belum sepenuhnya mengikuti aturan yang tertera dalam PMA No. 29. Walaupun ada kendala yang dihadapi terkait implementasi PMA ini yang masih membutuhkan sosialisasi terutama pada seluruh pengurus dan jamaah.

Penelitian ini merekomendasikan: (1) Penguatan karakter professional-religius bagi jamaah Majelis Taklim perlu diimplementasikan secara lebih nyata dalam program-progran jamaah majelis taklim agar jamaah memiliki berbagai pengetahuan dan keterampilan yang seimbang antara kepentingan duniawi dan ukhrawi. (2) Kementerian Agama agar membuat Juknis yang lebih rinci terkait implementasi dari PMA No. 29 Tahun 2019 tentang Majelis Taklim ini baik melalui Keputusan Dirjen Bimas Islam atau Regulasi lainnya, (3) Kementerian Agama perlu melakukan sosialisasi lebih baik lagi tentang implementasi PMA No. 29 tahun 2019 tentang Majelis Taklim ini kepada seluruh Kantor Wilayah Kementerian Agama Provinsi di seluruh Indonesia, dan juga kepada Kantor Kementerian Agama Kabupaten/Kota di seluruh Indonesia, karena untuk Kota Semarang sendiri, ketika penelitian ini dilakukan baru sebayak 25 Majelis Taklim yang terdaftar sesuai dengan Kriteria dalam PMA No. 29 Tahun 2019 tentang Majelis Taklim, (4) Kementerian Agama perlu merumuskan konsep moderasi beragama bagi Majelis Taklim sebagai tindak lanjut dari PMA No. 29 Tahun 2019 tentang Majelis Taklim, (5) KUA di Kota Semarang perlu membangun komunikasi dan silaturahmi yang efektif dengan seluruh Majelis Taklim, agar PMA No. 29 Tahun 2019 ini tersosialisasi dengan baik, (6) Para Penyuluh Agama Islam di Kota Semarang perlu membangun komunikasi dengan berbagai Ormas Keagamaan dalam mensosialisasikan PMA No. 29 Tentang Majelis Taklim ini, (7) Majelis Taklim di Kota Semarang diharapkan membaca dan mempelajari isi dari PMA No. 29 Tahun 2019 tentang Majelis Taklim ini, sehingga bisa mempersiapkan dan mendaftarkan diri kepada Kementerian Agama.

\section{UCAPAN TERIMAKASIH}

Peneliti mengucapkan terima kasih kepada Kepala Puslitbang Pendidikan Agama dan Keagamaan Badan Litbang dan Diklat Kementerian Agama RI yang telah memberikan kesempatan untuk melakukan penelitian ini. Terima kasih juga kepada rekanrekan peneliti Puslitbang Penda khususnya bidang Pendidikan Keagamaan yang sudah memberikan masukan dan meluangkan waktu untuk berdiskusi terkait hasil penelitian ini. Ucapan terima kasih juga penulis sampaikan kepada keluarga besar LDII Kota Semarang, khususnya Majelis Taklim Shirotol Mustaqim yang dengan senang hati menerima peneliti dan memberikan data dan informasi terkait penelitian ini.

\section{DAFTAR PUSTAKA}

Ahsanulkhaq, M. (2019) Membentuk Karakter Religius Peserta Didik Melalui Metode Pembiasaan. Jurnal Prakarsa Paedagogia, 2(1).

Al Faruq, U. (2020) Politik Dan Kebijakan Tentang Majelis Taklim Di Indonesia (Analisis Kebijakan Peraturan Menteri Agama No. 29 Tahun 2019). $A L$ MURABBI, 5(2), 41-59.

Al Ma'idha, F., Jannah, E. F., \& Arifin, I. (2021) Majelis Ta'lim Online Sebagai Wadah Pendidikan Dan Penguatan Karakter Mahasiswi Politeknik Elektronika Negeri Surabaya. AlMutharahah: Jurnal Penelitian Dan Kajian Sosial Keagamaan, 18(1), 2332.

Andrias, A. N. A. (2018a) Pendidikan Akhlak Sebagai Landasan Pembentukan Karakter Di Majelis Taklim Konversi Diniyah (MTKD) al ikhlas kec. Bandung Kulon. TEXTURA, 5(2), $137-$ 159.

Andrias, A. N. A. (2018b) Pendidikan Akhlak Sebagai Landasan Pembentukan Karakter di Majelis Taklim Konversi Diniyah (MTKD) al ikhlas kec. Bandung Kulon. TEXTURA, 5(2), 137159.

Anshori, I. (2017) Penguatan Pendidikan Karakter di Madrasah. Halaqa: Islamic Education Journal, 1(2), 63-74.

Chandra, P., Marhayati, N., \& Wahyu, W. (2020) Pendidikan Karakter Religius Dan Toleransi Pada Santri Pondok Pesantren Al Hasanah Bengkulu. Al- 
Tadzkiyyah: Jurnal Pendidikan Islam, 11(1), 111-132.

Dahlan, Z. (2018) Kebijakan Pemerintah Orde Baru Terhadap Majelis Ta'lim. Jurnal Al-Fatih, 1(1), 123-152.

Fransori, A., Sulistijani, E., \& Parwis, F. Y. (2019) Penyuluhan Pola Asuh Orang Tua Terhadap Anak Dalam Penguatan Pendidikan Karakter Anak Dan Literasi Digital Pada Ibu-Ibu Majelis Taklim Al-Hidayah Depok. Jurnal Pengabdian Masyarakat Ilmu Keguruan Dan Pendidikan (JPM-IKP), 2(01).

Ghazali, A. M. (2016) Toleransi beragama dan kerukunan dalam perspektif Islam. Religious: Jurnal Studi Agama-Agama Dan Lintas Budaya, 1(1), 25-40.

Hasan, H. (2017) Internalisasi Religius dalam Kompetensi Guru Agama Islam. Madaniyah, 7(2), 284-298.

Hubi, Z. B., \& Halimi, M. (2018) Tipe Dan Pola Pembentukan Sikap Wathaniyah (Kebangsaan) Yang Dilakukan Di Lingkungan Pesantren AlHikamussalafiyah Cipulus Purwakarta. JIPIS, 26(2), 38-47.

Ibrahim, I., Isa, A. H., \& Napu, Y. (2020) Peran Majelis Taklim Nurul Iman Dalam Meningkatkan Kehidupan Beragama. Jambura Journal Community Empowerment, 42-49.

Lubis, H. (2020) Model Dakwah LDII Yogyakarta dalam Penguatan Kerukunan Umat Beragama (Ditinjau dari Perspektif Manajemen Dakwah). Tadbir: Jurnal Manajemen Dakwah FDIK IAIN Padangsidimpuan, 2(1), 23-48.

Muchtar, D., \& Suryani, A. (2019a) Pendidikan Karakter Menurut Kemendikbud. Edumaspul: Jurnal Pendidikan, 3(2), 50-57.

Muchtar, D., \& Suryani, A. (2019b) Pendidikan Karakter Menurut Kemendikbud. Edumaspul: Jurnal Pendidikan, 3(2), 50-57.

Nurmawati, N. (2016) Kontribusi Majelis Ta' lim Dalam Menanamkan Nilai-Nilai Pendidikan Karakter Terhadap Remaja
Mesjid Desa Cinta Rakyat Kec. Percut Sei Tuan. TAZKIYA, 5(1).

Oktari, D. P., \& Kosasih, A. (2019) Pendidikan Karakter Religius dan Mandiri di Pesantren. Jurnal Pendidikan Ilmu Sosial, 28(1), 42-52.

Purnama, A. N., \& Sulistiyono, S. T. (2020)

Dari Ancaman Menuju Kekuatan: Perkembangan Lembaga Dakwah Islam Indonesia (LDII) Kota Semarang, 1970-2016. Historiografi, 1(1), 81-88.

Sarbini, A. (2010) Internalisasi Nilai Keislaman Melalui Majelis Taklim. Ilmu Dakwah: Academic Journal for Homiletic Studies, 5(16), 53-70.

Saridudin (2021) Pengembangan Pendidikan Karakter Dalam Pembelajaran PAI Pada Sekolah Menengah. OSF Preprints, 1 . https://doi.org/10.31219/osf.io/7p54a

Saridudin (2020) Pengembangan Kurikulum Pendidikan Diniyah Formal (PDF) di Pesantren Ulya Zainul Hasan Probolinggo. EDUKASI: Jurnal Penelitian Pendidikan Agama Dan Keagamaan, 18(1), 84-99.

St. Marwiyah. (2020) Peranan Majelis Taklim Untuk Meningkatkan Kesadaran Beragama. Palita: Journal of Social Religion Research, Vol.5, No.1 (2020), 77-90.

http://dx.doi.org/10.24256/pal.v5i1.140 4

Sudrajat, A. (2011) Mengapa pendidikan karakter? Jurnal Pendidikan Karakter, $1(1)$.

Tim Penyusun. (2013) Pedoman dan Silabus Majelis Ta'lim, Jakarta : Kementerian Agama RI Direktorat Jenderal Bimas Islam Direktorat Penerangan Agama Islam

Ta'rif, T. (2017) Pemberdayaan Perempuan di Majelis Taklim: Studi Kasus Majelis Taklim An-Nur Cibinong Bogor. EDUKASI: Jurnal Penelitian Pendidikan Agama Dan Keagamaan, 7 (4). https://doi.org/10.32729/edukasi.v7i4.26 2

Zakiyah Darajat, (1993), Ilmu Jiwa Agama. Jakarta: Bulan Bintang 